\title{
SCHOLARSHIP AND ACTIVISM TOWARD VIOLENCE AGAINST WOMEN
}

\author{
Nur Hasyim \\ Board of Directors of Rifka Annisa Yogyakarta \\ Master of Arts in Humanities Studies at Wollongong University, Australia \\ masnurhasyim@gmail.com
}

\begin{abstract}
This paper focuses on the relationship between scholarship and activism and argues that one is an integral part of another. Scholarship provides an analytical framework and guidance for activism in understanding the social injustice and oppression. It also help activism to develop strategies to address the problem. At the same time, activism provides a valid evidence and data from which theories are generated. Based on the author study on the movement to end violence against women, this paper indicates two types of relationship between scholarship and activism; first, direct connection in which the paper presents some examples of activismagainst violence against women in the world that are carried out by scholars. Second, indirect connection where the paper presents some scholarly works that are influential for anti-violence against women activism.
\end{abstract}

Keywords: scholarship, activism, violence against women, men's movement

\section{A. Introduction}

an a scholar be an activist or can an activist engage in scholarship work?". This is quite a popular question among scholars and activists. It triggers discussion on the connection and tension between the two areas. Furthermore, the discussion has a significant influence on changing the direction of the study of social science and humanities.

The issue of violence against women is one area which reflects the dynamic relationship between scholarship and activism, especially the involvement of men in the prevention of violence against women. There are many studies have been done by scholars to understand men's violence as well as possible strategies to engage them to end the violence. At the same time there is a growing movement which iscarried out by activists to put the mentioned studies into action. The global movements such as White Ribbon Campaign and Men Engage are good examples of how scholarship influences activism. Meanwhile, the Journal of Men's Studies and the Journal of Men and Masculinities are good examples of how activism leads to the development of scholarly works. In addition, 
there are many scholars who engage themselves within social movement and there are many activists who pursue postgraduate studies to advance their theoretical knowledge in order to sharpen their analytical capacities to understand the problems of injustice and oppression on the ground.

This paperwill address the dynamic connection between scholarship and activism in the issue of men's involvement in advocacy to prevent violence against women advocacy. The paper will focus on two types of connections between the two areas: first, direct connection where the paper will explore scholars who areinvolved in activism and vice versa. Secondly, it will explore the indirect connection between scholarship and activism which will discuss how theoretical frameworks which are produced by scholars influence the social movement, and how the practices of activism influence the process of shaping the body of knowledge within scholarly work. And, finally, the paper will draw conclusion based on the discussion.

\section{B. Direct Connection}

Ian Maxey (1999), a geographer at the University of Wales, Swansea, argues that activism is a daily reality of every person. By writing and reading a paper, someone actively engage in the process of producing the social world. Therefore, he rejects the binary scholarship and activism; he sees the roles of activists and scholars as fluid. ${ }^{1}$

Maxey's claim reflects that scholarly work is perceived as part of activism, and participating in the process of transforming social injustice and oppression is one of the responsibilities of the scholars. By doing so, scholars can perceive their work as politically relevant. However, not all academic works are politically relevant and have aims to transform social inequality.In fact, some of them legitimatise the problem and maintain and even reinforce the imbalanced power relationship in society. ${ }^{2}$

Within the context of men's involvement in the anti-violence against women movement, there are many forms of activism that are carried out by academics to address the problem. First, getting involved in a protest against the violence towards women, Michael Kaufman and the White Ribbon Campaign is one example of protest against the violence toward women when he and his colleague initiated a protest against women massacres in Montreal, Canada on December 6, 1989. Kaufman is well-known for his extensive work on men and masculinity. One of his papers entitled "The Seven P's of Men's Violence"provides a theoretical basis to understand the tendency of men to behave

\footnotetext{
${ }^{1}$ Maxey, I., 1999, 'Beyond boundaries? Activism, academia, reflexivity and research', Area, 31, 199-208.

2 Piven, F. F., 2010, 'Reflections on Scholarship and Activism', Antipode, 42, 806-810.
} 
violently. ${ }^{3}$ It is also frequently cited and referredto by scholars and activists to support their work and it was translated into twelve different languages. Before entering the activism world, Kaufman was a lecturer at York University, Toronto, Canada. The White Ribbon Campaign, the network that he and his colleague initiated, spread across the globe and is considered one of the largest men's networks against men's violence toward women in the world. ${ }^{4}$

The second example of activism by scholars in engaging men to end violence against women and to achieve gender equality is by getting involved in community education processes. Professor Bop Pease, a lecturer at the Deakin University, Australia, is among scholars who have long experience in conducting training on gender and violence against women for Australian men. His book entitled "Men and Sexuality Politics Toward a Pro-Feminist Practice" documents his extensive work in educating men in Australia. ${ }^{5}$ The book is considered as a personal, political and intellectual journey which clearly illustrates Maxey's claim that activism is the reality of everyone's life and how fluid are the roles of scholars and activists. Different from Kaufman, Pease started his career as a community development staff member and eventually he entered university as a lecturer. Similar to Kaufman, Pease become involved in organizing a men's group in Australia in December 1989; the name of the group is Men against Sexual Assault which is considered the first pro-feminist men's group in Australia.

The third example of activism by scholars is writing a report or other publication regarding men's violence against women. The report can be used as a counter argument for certain positions or it can be a reference for policy makers in producing policies in addressing the problems. In this case, what Michael Flood has done when he wrote a paper in response to Men's Health opposition against the claim of White Ribbon Campaign Australia on violence against women in Australia is one good example of scholarlyactivism. ${ }^{6}$ By using the statistical data on violence against women in Australia, Flood countered Men's Health claim that men and women have the same vulnerability to become victim of violence. Through various statistical data, Flood argues that women are more vulnerable than men. Furthermore, as an ambassador of White Ribbon Campaign Australia anda senior lecturer at the University of Wollongong, Michael Flood is one example of the direct connection of scholarship and activism.

3 Kaufman, M., 1999, The Seven P's of Men's Violence [Online]. Toronto. Available: http://www.michaelkaufman.com/wp-content/uploads/2013/03/Kaufman-7-Ps-of-Mens-Violence.pdf [Accessed 9 June 2013].

${ }_{5}^{4}$ Anonymous, 1998, 'The White Ribbon Campaign',Journal of Family and Consumer Sciences, 90, 69-69.

5 Pease, B., 1997,Men and Sexual Politics Towards Profeminist Practice, Adelaide, Dulwich Centre Publications.

${ }^{6}$ Flood, M., 2010, A Response to Criticisms of White Ribbon Materials Made by Men's Health Australia [Online]. Available: http://www.menshealthaustralia.net/storage/files/Response-to-Mens-HealthAustralia-criticisms-REVISED.pdf [Accessed 10 June 2013]. 
There are always challenges and tensions when discussing male scholars who engage in anti-violence against women. This is because scholars are not merely working on their desks, libraries or laboratories but they actively challenge the oppressive structures in their own society. There are numbers of challenges that might be encountered by scholars who are activists; first, attack from the political opponent. The action usually aims to silence the scholars/academics and to prevent the political impact of their works. ${ }^{7}$ The attack can be in various forms, such as sending hate email, making threats of violence, and sending complaints to the employers or funding agency demanding budget termination. The attack that was faced by Michael Flood is an instance of this challenge when he received hostile and abusive correspondence, including mails, phone calls and web postings as a result of his criticism toward anti-feminist and fathers' right group in Australia. Flood was also being questioned by his university for the anti feminist group's allegation that he had behaved dishonestly and unethically in his research and public commentary. ${ }^{8}$

The second challenge is output expectation. In the academic world, scholars are requested to engage in intelectual debate in their descipline. Therefore, they have to conduct their own research, write articles for prestigious journals or present papers in international scientific conferences. The involvement of scholars in activism may influence their productivity in creating scholarly work. Although they are still productive, they will find another challenge that the prestigious journal and the conferences are not interested in activist-scholarship works.

To deal with this challenge, scholars may create their own channel or outlet to publish their scholarly activism work to reach a broader audience. However, it demands a significant effort and energy which is not always easy for the scholars.

The third challenge of scholarly activism is epistimological challenge. This is related to academic culture in which scholars are requested to follow scientific tradition. This means that the scholars have to stick to the science by applying academic framework in their work. They have to employ methodological tradition in their descipline. Therefore, other framework outside scientific tradition will be eliminated.

Output and epistemological challenges may put a scholar's career at risk or at least scholars must advocate their concern in their own institution in order to accommodate activism as an integral part of their scholarship tradition. The scholars must also have creative strategies to deal with these challenges, otherwise they will be exluded from the scholarship community.

\footnotetext{
${ }^{7}$ Flood, M., Martin, B., Tanja, D., 2013,'Combining Academia and Activism: Common Obstacles and Useful Tools', The Australian Universities' Review 55, 17-26.

${ }^{8}$ Ibid.
} 


\section{Indirect Connection}

The second type of connection between scholarship and activism is indirect connection in which scholarship produced numerous analytical frameworks that are useful and frequently used as guidance for activism and vice versa, social activism provides empirical data to generate theories for the scholarship world.

Within the context of men's involvement in anti violence against women advocacy, there are many influential theoretical frameworks that are developed by scholars which are commonly used by activists in the field. First, ecological framework which was introduced by Lori Heise. The framework was generated from large scale population based research on violence against women. It provides guidance in understanding multilayer factors that trigger men's violence against women. According to the framework, that individual male who witnesses marital violence when he was child, being abused or grown up without a consistent or available father is more likely to become violent than other individual males. The violence is also more likely to occur within the family where males are dominant, take control of family wealth and use alcohol. The violence also tends to happen in the family where verbal conflict is frequent. Other factors beyond individual history and family level are exo system which is related to social and economic status of men and women and macro system level which is related to beliefs and norms with regard to men and women in society. For example, violence against women is more likely to happen in the community where men are considered as the owner of women, manhood is defined by aggression and dominance, and there is acceptance toward interpersonal violence. ${ }^{9}$

The ecological framework guides activists in many ways, for instance, it provides comprehensive tool for activists in conducting assessment about violence against women problem in society. The framework allows them to gain a complete picture of the problem on which intervention strategies can be designed and developed.

The framewok helps activists to avoid a narrow perspective in looking at men's violence against women, such as seeing men's violence merely about personal disorder (poor impulse control) and ignore other aspects beyond individual (family, society or state aspect) or seing the violence in a very abstract perspective (looking at men's violence as a result of patriarchal ideology that give men more privilege and power over women) and ignore individual aspects of the problem.

The framework also helps actvists to map available intervention for men's violence against women in the world and suggests possible integration of available strategies which are carried out by service providers, non-goverment organizations, goverments and other agencies. This integration enables activists to an establish integrated system in response to men's violence against women.

\footnotetext{
${ }^{9}$ Heise, L., 1998, 'Violence against Women: An Integrated, Ecological Framework', Violence Against Women, 4, 262-290.
} 
The second theory is hegemonic masculinity concept. It is introduced for the first time in reports from the study of social inequality in Australian High Schools. Hegemonic masculinity concept was generated from the report that provided an evidence of multiple hierarchies within gender and class. The concept is understood as a practice which allows men to dominate women as well as another men who are considered as a subordinated masculinities. ${ }^{10}$

The discource of hegemonic masculinity helps activists, especially male activists, to understand deeply that masculinity is produced and reproduced by social structures in society. As socially constructed product masculinity is not merely influenced by gender, but other social determinants as well, such as class, ethnicity, age, sexual identity, and disability. Therefore, masculinity takes many forms which depends on its context and the relationship between masculinities are hierarchical rather than equal.

The concept of hegemonic masculinity also plays an important role in introducing the linkage between gender and other social structures on which intersectionality analysis is built. By applying the analysis, enable male activists to put the struggle to eliminate violence against women as part of another strugle to eradicate social injustice and oppression.

The concept helps activists to reveal that men's violence is not only toward women, but it also happens toward other men who are considered as marginalized or subordinated masculinity. Therefore, by applying the concept, activists are able to understand the discrimination and oppression against gay men, transgenders, and other minority men's group. In addition, the concept also provides an explanation about the violence among men themselves as a process of power battle to gain the top position within the social hierarchy.

The other important contribution of hegemonic masculinity concept to activism in violence against women prevention is the introduction ofthe concept of negative cost of masculinity. The dominant masculinity which is characterized by superiority, physical strengh, toughness and repression of emotion has prevented men to be fully human. ${ }^{11}$ Men ignore or even repress, their feminine side such as their potential to be caring and loving and as a consequence of this, men have difficulties in buiding emotional connection with their children and partner. ${ }^{12}$ The negative cost of masculinity becomes an effective starting point to tranform men's perceptions, beliefs and norms regarding manhood. And this transformation is a valuable component for eliminating violence against women and achieving gender equality.

\footnotetext{
${ }^{10}$ Connel, R. W. \& Messerchmidt, J. W., 2005,'Hegemonic Masculinity: Rethinking the Concept',Gender and Society, 19, 829-859.

${ }^{11}$ Lang, J., 2002, Men, Masculinities and Violence. International Conference "Eradicating Violence against Women and Girls - Strengthening Human Rights". Berlin.

${ }^{12}$ United Nations, 2008, The Role of Men and Boys in Achieving Gender Equality.
} 
Finally, It is obvious that the concept of hegemonic masculinity is vital for engaging men in achieving gender equality and violence against women prevention. That is why, among other things, that the concept becomes one key theme of training manuals for male activists in many parts of the world.

The third theoretical framework is men's pathways to anti violence against women involvement. The framework was introduced by Erin Casey and Tyler Smith (2010) who are scholars at the University of Washington. While two previous frameworks represent how scholarly works influence activism, men's pathway framework describes the influence of activism in shaping the body of knowledge in scholarly work, especially in developing theory on men as allies in ending violence towards women. Based on an interview of 27 male activists who engage in violence against women prevention, the framework explains the pathway through which men get involved in anti violence against women activism. ${ }^{13}$

According to Casey and Smith, there are three main stages of men's involvement in anti violence against women movement. Firstly, sensitizing experience in which men having new consiousness regarding violence against women. This experience can be witnessing their friends being abused by their boy friends or partners, and even, they themselves experience the violence within their own family. Secondly, opportunity experience in which men have a chance to participate in the movement due to their professors, friends or aqcuaintances nominate or suggest to them to be part of anti violence against women groups. Thirdly, shifting meaning in which men have new meaning that they attach to sensitizing and opportunity experiences. These new meanings become motivating factors for men to engage in violence against women prevention.

Men's pathway in anti violence against women involvement is considered as an initial work in developing theory on men as allies of feminist movement and it enriches ally development theories in other social justice arena. Furthermore, the framework also inspires activists on how to develop strategies in engaging men and boys in violence against women prevention.

\section{Conclusion}

This paper argues that scholarship and activism within social science and humanities are like two sides of the same coin, which means that one is an integral part of another. Intellectual activities have aimed to develop theories, provide an analytical framework and guidance for activism in understanding the social injustice and oppression. It also help activism to develop strategies to address the problem. At the same time, activism provides a valid evidence and data from which theories are generated. Therefore,

\footnotetext{
${ }^{13}$ Casey, E. \& Smith, T., 2010, “How Can I Not?”: Men's Pathways to Involvement in Anti-Violence Against Women Work', Violence Against Women, 16, 953-973.
} 
the paper argues that the separation of these two areas within the social science and humanities is not relevant.

In addition, activism has a significant influence in changing the direction of social science and humanities. The popularity of social movement within the field of study allows critical thinkers such as Karl Mark, Michael Foucault, and others to become important sources in the field. This supports Piven's claim that after the 1970's, when activism had a great impact on social change, there was a trend among the young generation who entered university that besides studying they wanted to be activists. ${ }^{14}$

${ }^{14}$ Piven, F. F., 2010, 'Reflections on Scholarship and Activism', Antipode, 42, 806-810. 


\section{Bibliography}

Anonymous, 'The White Ribbon Campaign',Journal of Family and Consumer Sciences, 1998.

Casey, E. \& Smith, T., “How Can I Not?": Men's Pathways to Involvement in AntiViolence Against Women Work', Violence Against Women, 2010.

Connel, R. W. \& Messerchmidt, J. W., 'Hegemonic Masculinity: Rethinking the Concept', Gender and Society, 2005.

Flood, M., 2010, A Response to Criticisms of White Ribbon Materials Made by Men's Health Australia [Online]. Available: http://www.menshealthaustralia.net/storage/files/Response-to-Mens-HealthAustralia-criticisms-REVISED.pdf [Accessed 10 June 2013].

Flood, M., Martin, B., Tanja, D., 'Combining Academia and Activism: Common Obstacles and Useful Tools', The Australian Universities' Review 55, 2013, 17-26.

Heise, L., 'Violence against Women: An Integrated, Ecological Framework', Violence Against Women, 1998.

Kaufman, M., 1999, The Seven P's of Men's Violence [Online]. Toronto. Available: http://www.michaelkaufman.com/wp-content/uploads/2013/03/Kaufman-7-Ps-ofMens-Violence.pdf [Accessed 9 June 2013].

Lang, J., Men, Masculinities and Violence. International Conference "Eradicating Violence against Women and Girls - Strengthening Human Rights". Berlin, 2002.

Maxey, I., 'Beyond boundaries? Activism, academia, reflexivity and research', 1999.

United Nations, The Role of Men and Boys in Achieving Gender Equality, 2008.

Pease, B., Men and Sexual Politics Towards Profeminist Practice, Adelaide, Dulwich Centre Publications, 1997.

Piven, F. F., 'Reflections on Scholarship and Activism', Antipode, 2010.

Teosofia: Indonesian Journal of Islamic Mysticism, Volume 6, Number 1, 2017 
